\title{
Age and growth of sea trout, Salmo trutta L., from new commercial catches in the lower Vistula River
}

\author{
Rafał Bernaś, Anna Wąs-Barcz, Grzegorz Radtke
}

Received - 21 February 2019/Accepted - 01 June 2019. Published online: 30 June 2019; Inland Fisheries Institute in Olsztyn, Poland Citation: Bernaś R., Wąs-Barcz A., Radtke G. 2019 - Age and growth of sea trout, Salmo trutta L., from new commercial catches in the lower Vistula River - Fish. Aquat. Life 27: 72-79.

\begin{abstract}
The age and growth of Vistula River migratory sea trout, Salmo trutta L., caught in commercial catches in the Vistula in 2017-2018 were analyzed. The mean length of the sea trout caught was $61.4 \mathrm{~cm}$ in 2017 and $62.8 \mathrm{~cm}$ in 2018. It was confirmed that the fish caught reached an average of 56.5 $\mathrm{cm}$ following the first year at sea, $69 \mathrm{~cm}$ after the second year, and $82 \mathrm{~cm}$ after the third. The dominant age class among the fish in the catches was a sea age $1+$. No older age classes than $3+$ were noted. The age at smoltification of the sea trout examined in most instances was $2+$. The results obtained were compared and discussed in light of historical results. The condition coefficient calculated was lower than that of the 1960 s.
\end{abstract}

Keywords: age structure, sea trout, Vistula River

\section{Introduction}

The Vistula River is the longest river draining into the Baltic Sea, and its discharge is second only to

\footnotetext{
R. Bernaś [ $\equiv]$, G. Radtke

Inland Fisheries Institute in Olsztyn

Department of Migratory Fishes, Rutki 49, 83-330 Zukowo, Poland

e-mail: r.bernas@infish.com.pl

A. Wąs-Barcz

National Marine Fisheries Research Institute,

Department of Fisheries Resources, Kołłątaja 1, 81-332 Gdynia,

Poland
}

that of the Neva River (BACC II). Formerly, the Vistula has an abundant, and possibly the largest (Dębowski 2018), migratory sea trout, Salmo trutta L., population in the Baltic drainage basin. The primary spawning grounds of this population were located in Carpathian tributaries that were as far as a thousand kilometers from the river mouth. This population collapsed in the late 1960s, mainly because of the effect of damming the Vistula in Włocławek, but also because of the earlier, continual construction of barriers on main tributaries and overfishing (Bartel et al. 2007, Dębowski 2018). After 1969, decreased river catches were noted, while no catches were made in the upper segments of the drainage basin and those in the lower segments decreased to very low levels in the course of a few years (Radtke et al. 2017). Additionally, the fishway installed at Włocławek proved to be ineffective (Bontemps 1977). The fishway was not modernized until 2014, and to date several thousand sea trout have ascended the upper Vistula through it (Dębowski 2018). Since 1968, the size of the Vistula sea trout population has been supported largely by stocking programs, and natural spawning occurs in a limited range of small tributaries in the lower Vistula (Zielona Struga, Mień, Tążyna, Dopływ z Solca Kujawskiego) and accessible segments of major

\footnotetext{
(c) Copyright by Stanisław Sakowicz Inland Fisheries Institute in Olsztyn.

C 2019 Author(s). This is an open access article licensed under the Creative Commons Attribution-NonCommercial-NoDerivs License (http://creativecommons.org/licenses/by-nc-nd/3.0/).
} 
tributaries (Wierzyca, Wda, Brda, Drwęca). The intensity of the stocking currently performed is high, and in the last decade the Vistula River drainage basin has been stocked with about 700,000 smolts annually and with several million specimens of younger forms (alevins, fry; ICES 2018). The age structure and growth of migratory sea trout from the Vistula River was described several times in the twentieth century (Dixon 1931, Żarnecki 1957, Pałka and Bieniarz 1983, Borzęcka 1999, 2001), and the problem of the reliability of identification was the subject of detailed studies (e.g., Backiel and Sych 1958, Sych 1967). However, the most recently published analyses date to thirty years ago. Additionally, taking into consideration climate change and changes that are fundamentally anthropogenic (excluding stocking methods or fishing techniques), these data must be updated. The aim of the current paper is to present the age structure of migratory sea trout originating from commercial catches in the Vistula River in the 2017 and 2018 seasons and to compare the results obtained with historical data.

\section{Materials and methods}

Sea trout specimens were selected from among fish caught in Vistula fisheries districts No. 4, 5, and 6 in the lower Vistula River in fall 2017 and throughout the 2018 fishing season from March to December. In total, the scale material analyzed was collected from 370 sea trout specimens: 74 from fall 2017 and 296 from 2018 (Fig. 1). The fish were caught with drifting gill nets by commercial fishers. The fish were measured to the nearest $0.5 \mathrm{~cm}$ (TL). About fifteen scales were collected along the lateral line in a vertical line from the back edge of the dorsal fin on each specimen (Shearer 1992). Some of the specimens (98 individuals) caught in the spring-summer season (from March to August) and in fall (September - December) in 2018 were also weighed, without evisceration, to the nearest $10 \mathrm{~g}$.
Sex was also determined, with the exception of some silver fish. The scales collected were cleaned and the material was examined by two independent readers using a Bell\&Howell Ak-IV reader. Sea age, and, when possible, age at smoltification were determined. This is how the age structure of the sample was determined. Silver sea trout is a term that refers to sea trout that have recently entered the sea and are not in a spawning period and their bodies are characterized by an intense silver coloration and a strong profile. Sea age is understood as the growth period in marine waters as opposed to the growth period in fresh water (Sych 1967). Next, Fulton's condition coefficient (K) was calculated for spring-summer and fall fish segregated by sex with the formula $\mathrm{K}=\mathrm{W} \times$ $\mathrm{TL}^{-3}$, where $\mathrm{W}$ is body weight in gr and TL is total length in $\mathrm{cm}$. Length and weight dependencies were also calculated for both groups and for the entire sample following log transformations with the formula $\log \mathrm{W}=\mathrm{b} \times \log \mathrm{L}+\log \mathrm{a}$, where $\mathrm{W}$ is body

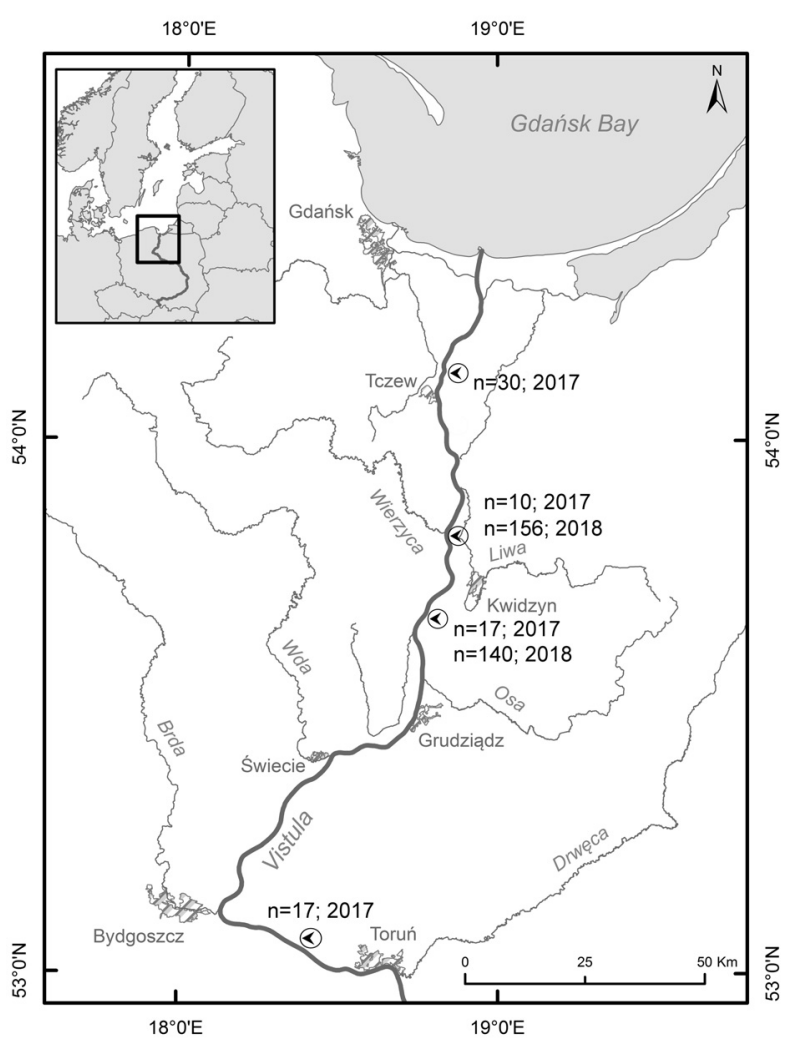

Figure 1. Sea trout (S. trutta) sampling sites in the lower Vistula River in 2017 and 2018. 
Table 1

Mean standard length (SL) of S. trutta in the lower Vistula River in 2017 and 2018 by sex

\begin{tabular}{lllll}
\hline \hline Season & Collectively & Females & Males & $\mathrm{N}$ \\
\hline \hline Autumn 2017 & 61.29 & 61.52 & 59.6 & 74 \\
Spring-summer 2018 & 62.35 & 64.05 & 62.73 & 205 \\
Autumn 2018 & 63.95 & 65.45 & 59.09 & 91 \\
All 2018 & 62.81 & 64.67 & 60.82 & 296 \\
\hline \hline
\end{tabular}

weight, TL is total length, $a$ and $b$ are parameters describing the regression equation (Ricker 1975).
Statistical calculations were performed with Statistica 8.0 (StatSoft Inc., Tulsa, OK, USA).

\section{Results}

The mean length sea trout caught in fall 2017 was $61.42 \mathrm{~cm}$ and by sex it was $61.80 \mathrm{~cm}$ for females and $58.60 \mathrm{~cm}$ for males (Table 1). In 2018, the mean value for the entire year was $62.80 \mathrm{~cm}$, while for females it was $62.08 \mathrm{~cm}$ and for males it was $60.82 \mathrm{~cm}$. Significant differences were confirmed between female and male body lengths in the seasons analyzed (t-test, $\mathrm{P}=$ 0.01) (Table 1). The mean body weight of sea trout caught in the spring-summer period of 2018 was 3.76 $\mathrm{kg}$, while in the fall period it was $3.36 \mathrm{~kg}$.
Sea trout sea age was determined in both 2017 and 2018 and for each of the periods in 2018, and the majority consisted of sea trout that had spent one year in the sea. In 2017, this sea age class was 59\% of the sea trout caught, and in 2018 a total of $53.5 \%$ of the sea trout caught were this age (Fig. 2). In 2017, $39 \%$ of the sea trout caught were sea age $2+$, while in $201840 \%$ were. Sea age 3+ was confirmed in $1 \%$ of the sea trout caught in 2017 and $4.7 \%$ of those caught in 2018. No fish of sea age $4+$ or $5+$ were noted in either of the years analyzed. Sea trout that

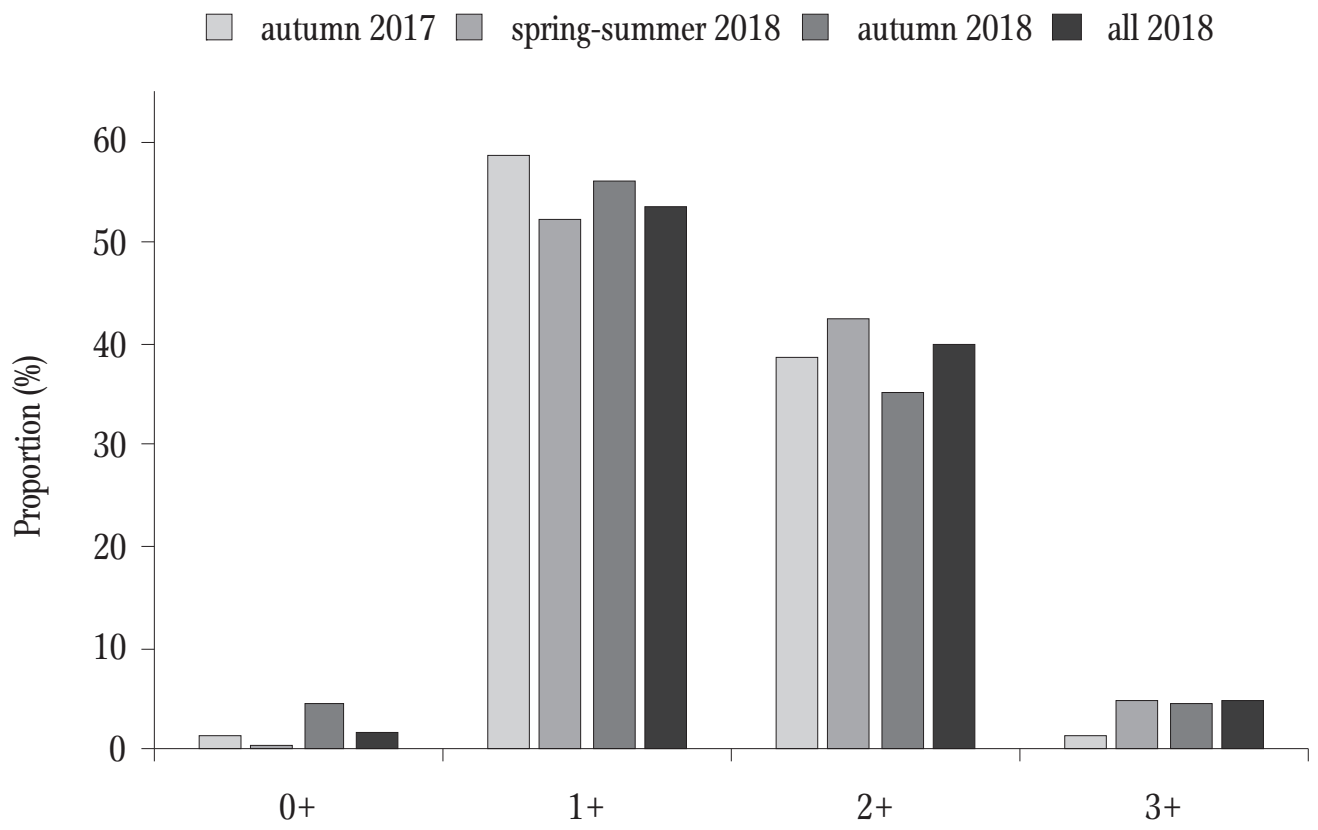

Figure 2. Age group structure in sea trout (S. trutta) catches in 2017 and 2018. 


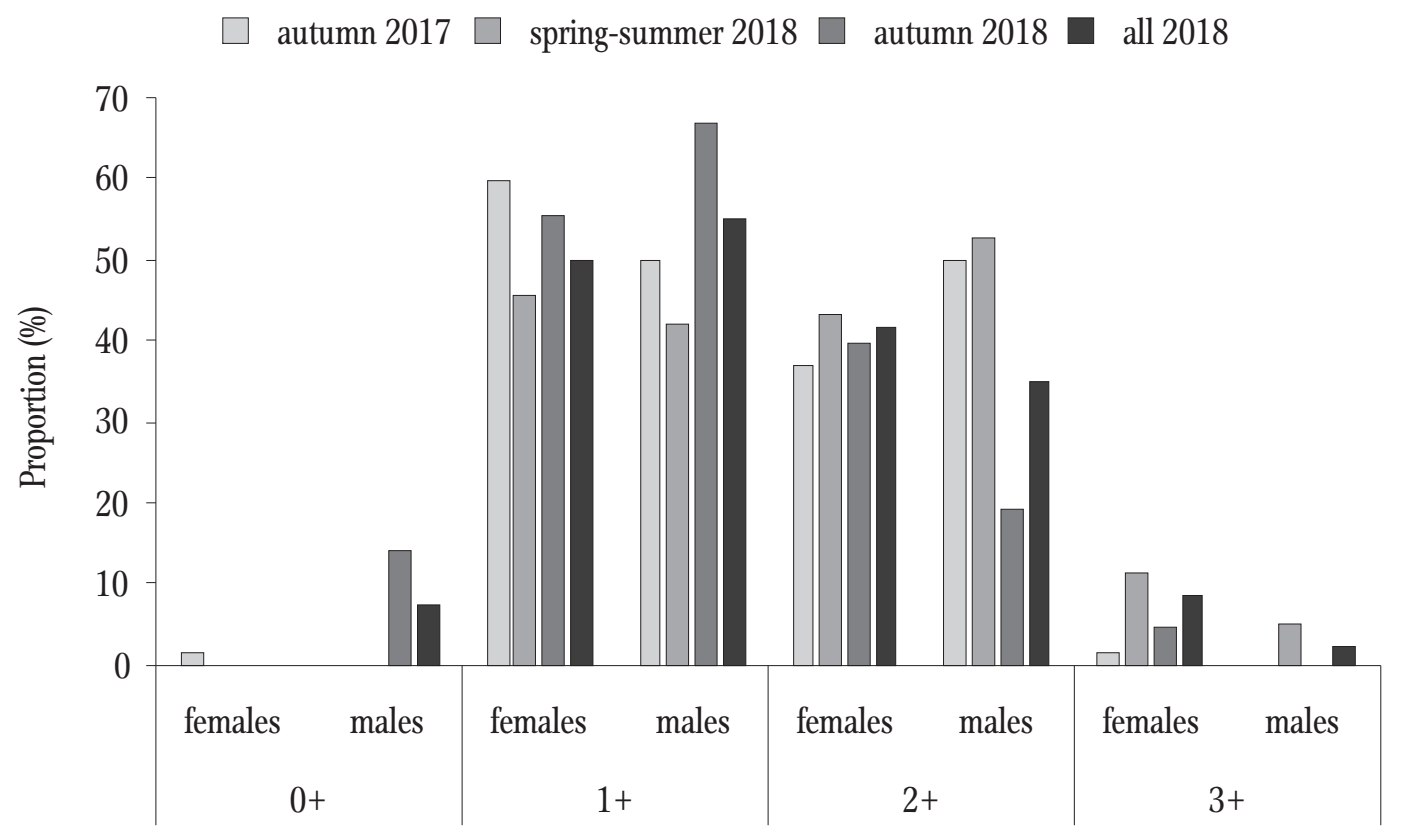

Figure 3. Estimated sea age distributions of male and female sea trout (S. trutta) based on catches in 2017 and 2018. Total number of observations is 370 fish.

returned to the Vistula in the year of smoltification (sea age $0+$ ) was just $1 \%$ in 2017 and $1.69 \%$ in 2018 . The breakdown of sea age class shares by sex in the different periods also indicated that the dominant age class was $1+$ (Fig. 3). Comparing the sexes did not reveal any significant differences in the age class shares for this age class (Chi-square test, $\mathrm{P}=0.2$ ). However, significant differences were noted for sea age $2+$ that stemmed from a larger share of this age class in the spring-summer 2018 period (Chi-square test, $\mathrm{P}=0.00)$. When the river and sea ages were combined, no fish older than $6+$ were noted.

Sea trout body length at sea age $0+$ without segregation by sex and combined for 2017 and 2018 was a mean of $47 \mathrm{~cm}$ (SD 3.7) at a range of 42-51 cm. At sea age $1+$, the mean length of the sea trout caught was $56.5 \mathrm{~cm}$ (SD 5.9) at a range of 40-69 cm. The mean length of older fish of sea age $2+$ was $69.13 \mathrm{~cm}(\mathrm{SD} 4.1)$ at a range of $59-79 \mathrm{~cm}$. The oldest sea age noted was $3+$, while mean length was 82.2 $\mathrm{cm}$ (SD 5.7) and the range was 70-95 cm.

In both of the years analyzed, the predominance of females in the catches in both years was decisive at $87.6 \%$ in 2017 and $78.02 \%$ in 2018 . It was impossible to directly determine the sex of the silver sea trout caught in the spring-summer period of 2018; their share of the entire sample in 2018 was $20.06 \%$.

A reliable smoltification age was determined only for some individuals from the seasons analyzed. This stemmed from the frequent presence of regeneration in the centers of the scales. In 2017, 57\% of the sea trout specimens were analyzed, and in 2018, $25 \%$ of them were analyzed. Fish of smoltification age $2+$ predominated in both seasons with $95.2 \%$ in 2017 and $83.79 \%$ in 2018. The smoltification age $1+$ was confirmed in $2.4 \%$ of the sea trout in 2017 and in

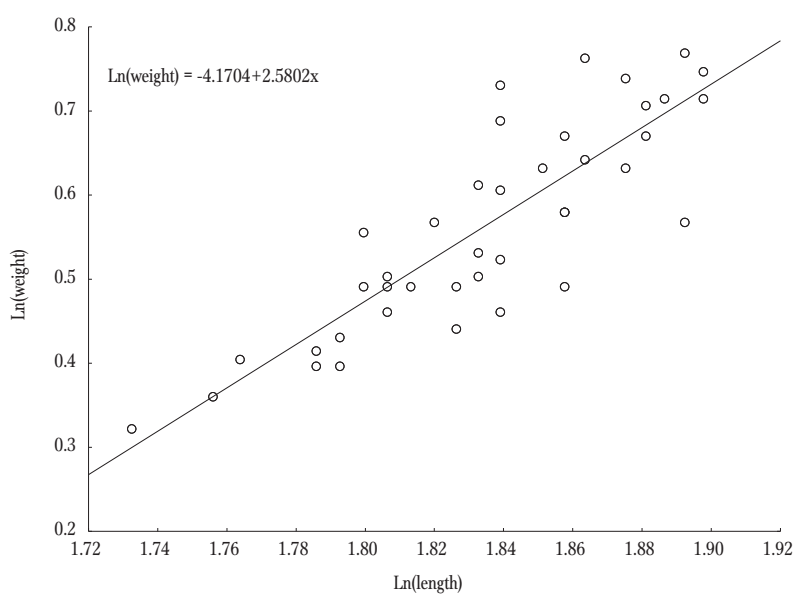

Figure 4. Length-weight relationship of sea trout (S. trutta) from spring-summer 2018. 


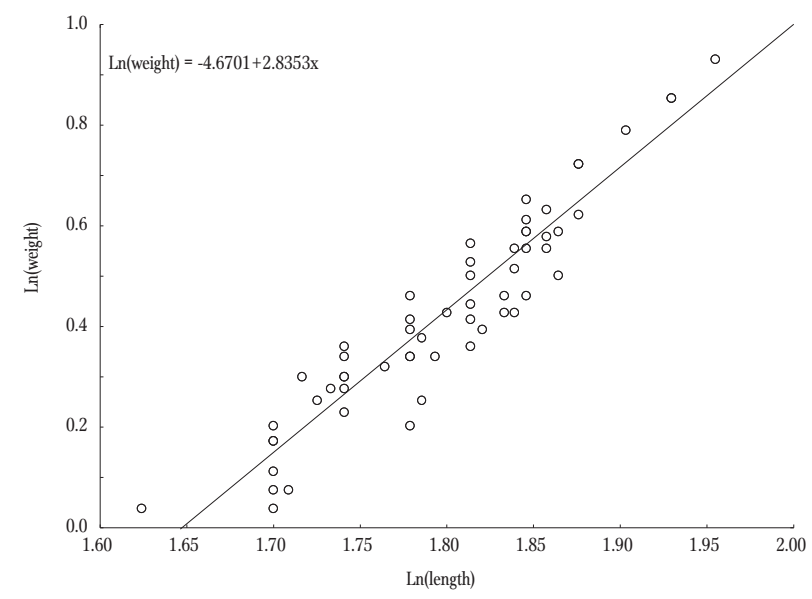

Figure 5. Length-weight relationship of sea trout ( $S$. trutta) from autumn 2018.

$16.21 \%$ in 2018 . In the 2017 sample, $2.4 \%$ of the sea trout were confirmed to be river age $3+$. The dependence between body weight and length was calculated separately for the sea trout from the spring-summer period and from the fall in 2018 (Figs 4 and 5).

The value of exponent $b$, which describes the body weight growth rate as length increases, was lower in the groups of specimens from the spring-summer period and was 2.58; however, the value of this exponent in fall sea trout was 2.83 .
$P=0.13)$. For the sake of comparison, data from the literature was also collected that describes the mean body length of sea trout in subsequent sea age years, and it is presented in Table 2 .

\section{Discussion}

Historical data indicate that in the early twentieth century Vistula sea trout that smoltified in the second year and were caught in the vicinity of Nowy Targ reached sizes of $48 \mathrm{~cm}$ at a sea age of $1+, 63$ $\mathrm{cm}$ at $2+, 80 \mathrm{~cm}$ at $3+$, and $83 \mathrm{~cm}$ at $4+$, while smolts that were aged $3+$ measured $49 \mathrm{~cm}$ for $1+$, $71 \mathrm{~cm}$ for $2+$, and $77 \mathrm{~cm}$ for $3+$ (Dixon 1931). Results from the 1950 s are similar and indicate that after the first year in the sea Vistula sea trout reached sizes of 47-52 $\mathrm{cm}$, after the second year 65-70 cm, after the third year 80-87 cm, and after the fourth year 88-95 cm (Żarnecki 1957). More recent papers that are based on samples from the 1960 s indicate that at sea age $1+$ sea trout smolts aged $2+$ reached $67 \mathrm{~cm}$ and in the second year 79.5 $\mathrm{cm}$. These results refer to the winter sea trout form that was classified based on scale characters, e.g.

Table 2

Mean standard length (SL) of S. trutta in the lower Vistula River in subsequent sea age classes based on data from the literature

\begin{tabular}{llllll}
\hline \hline Author & Collecting date & $1+$ & $2+$ & $3+$ & $4+$ \\
\hline \hline Dixon (1931) & 1928 & 48 & 63 & 80 & 83 \\
Żarnecki (1957) & 1956 & 49.5 & 67.5 & 83.5 & 91.5 \\
Borzęcka (2001)* & $1960-1968$ & 58 & 70 & 81.5 & 93 \\
Pałka and Bieniarz (1983) & $1964-1970$ & 58.3 & 68.9 & 81.5 & 92.8 \\
Bartel et al. (2010) & $1972-1977$ & 51 & 69.6 & 78.7 & \\
Bartel et al. (2001) & $1980-1984$ & 47 & 63 & & 82.2 \\
Bernaś et al. (this study) & $2017-2018$ & 56.5 & 69.1 & & \\
\hline \hline
\end{tabular}

* summer form

Fulton's condition coefficient for the specimens caught in spring-summer 2018 was 1.17 , while that for the fall group was 1.16. The comparison of the condition of females from both periods did not indicate any significant differences among the seasons (ANOVA, $\mathrm{P}=0.12$ ), similarly to the males (ANOVA, time of smoltification (Żarnecki 1963, Borzęcka 2001). The values for the summer form of sea trout were $58 \mathrm{~cm}$ for $1+, 68.9 \mathrm{~cm}$ for $2+, 81.5 \mathrm{~cm}$ for $3+$, and $92.8 \mathrm{~cm}$ for $4+$ (Borzęcka 2001). Interestingly, seasonal forms still occur in the Vistula despite significant migration difficulties and the inaccessibility 
of the spawning grounds in the Carpathian tributaries of the Vistula. It was impossible, however, to confirm the difference between the currently occurring summer sea trout form, at least when using neutral genetic markers (Wąs and Bernaś 2016). It could be that this phenomenon results simply from the biology of the species and variable life strategies (Jokiel 1961, Dębowski 2018) or that it requires applying genetic markers from the coding regions. The results of sea trout migration studies and growth from tagging experiments in the 1960s indicate that after the first year in the sea, the sea trout were an average of $58.3 \mathrm{~cm}$, after the second 69.4, after the third 75.9, and after the fourth $106 \mathrm{~cm}$ (Pałka and Bieniarz 1983). Results from smolt tagging experiments performed in the 1970s indicate that after the first year in the sea, sea trout reached an average size of $51 \mathrm{~cm}$, after the second $69.6 \mathrm{~cm}$, and after the third $78.7 \mathrm{~cm}$ (Bartel et al. 2010). Similarly, in the early 1980 s the average growth observed in the first year in the sea (until March) for sea trout smolts released at age 2+ into the Vistula River mouth was $47 \mathrm{~cm}$, and after the second year it was $63 \mathrm{~cm}$ (Bartel et al. 2001). Comparing the growth of migratory sea trout from various regions of the Baltic Sea indicates that the southern population exhibits faster growth than that of the northern population. The growth of sea trout from the southern area of the Gulf of Bothnia is significantly faster than that of fish from the northern area of the gulf (Degerman et al. 2012, Kallio-Nyberg et al. 2017). Similarly, sea trout growth in the Gulf of Finland is slower than that in the Bay of Gdańsk (Bartel et al. 2001). These differences stem mostly from different environmental conditions, and primarily from water temperature, which, for example, was demonstrated by stocking experiments that released specimens of the Vistula population into the Gulf of Finland and specimens from the Isojoki River into the Bay of Gdańsk (Bartel et al. 2001).

The historical data presented indicates that the growth rates of sea trout did not change substantially and that they were similar to the results of the present study. Small differences could stem from natural variability in environmental and population factors or from methodological differences. However, a shift in the age of the Vistula sea trout stock was observed. In the present study of two seasons, specimens of sea age $1+$ predominated decidedly. Older fish aged 2+, and especially $3+$, were less abundant. As was already mentioned, fish older than $3+$ were not observed. The results of long-term observations from 1953 to 1968 indicate that the winter form of sea trout aged $2+$ dominated (mean 51.4\%), but that the summer form dominated even more decidedly (60.3\%), although seasons were noted when the dominant sea age was $1+$. In this period, older fish accounted for 4 and 14\%, respectively. More recent results from the late 1980s from the Drwęca River indicated that sea trout of sea age $1+$ accounted for $37 \%$ and that most of the stock consisted of fish of sea ages of $2+$ at $53 \%$ and $3+$ at $8.5 \%$ (Borzęcka 2003). The reason for this change is unclear; it could have stemmed from natural fluctuations, fishing pressure or varied stocking effectiveness, and it requires further observations.

Comparing sea trout smoltification age from the current study with historical results did not reveal any differences. Smolts aged $2+$ dominated in both seasons analyzed. Similarly to previous studies, the significant domination of smolts aged 2+ was noted, and they contributed from 75 to $90 \%$ of all fish (Borzęcka 1999, Borzęcka 2003). It must be underscored here that a significant portion of scales in the current analysis could not be read reliably because of the regeneration of the center of the scales. This could be indicative of the aquaculture origin these fish, especially since the Vistula River is stocked almost exclusively with smolts aged $2+$.

The sex structure of sea trout from catches in 2017 and 2018 revealed the decided domination of females (87\% in 2017 and 78\% in 2018). Such a sex distribution in a migratory sea trout population is natural and has been described by other researchers for different populations (e.g., Chełkowski 1974, Jonsson et al. 2001). Older data from the Vistula indicates that in 1960-1968 females comprised 86\% of the winter sea trout and $78 \%$ of the summer form (Borzęcka 2003). 
Comparing the values of sea trout condition coefficients from the 2017 and 2018 seasons with those of earlier years indicates there was a slight change for the worse. The values of the coefficient for sea trout from the Vistula in the 1962 and 1963 seasons fluctuated from 1.26 to 1.32 depending on the sample (Borzęcka 2001). In more recent studies, fish from the Drwęca River had condition coefficient values similar to the present study at 1.09 (Borzęcka 2003). The values of exponent $b$, which is the dependence of body weight and length, were lower than in earlier studies and especially for samples collected during the summer period (2.58). This could have been linked to the occurrence in the catches of spent fish. On the other hand, the mean sea age weight from the spring-summer period was slightly higher, which could have been explained by the domination in the catches of strong, silver fish caught in late June and early July.

Acknowledgments. This study was partially funded by statutory topic S-30 at the Inland Fisheries Institute in Olsztyn and the GENZAR/17 - GENZAR/18 projects at the National Marine Fisheries Research Institute, Gdynia.

Author contributions. R.B. and A.W.B. conceived of the study. R.B. collected the samples. R.B. and G.R. analyzed the data. R.B. and A.W.B. wrote the paper.

\section{References}

BACC II Author Team 2015 - Second Assessment of Climate Change for the Baltic; Regional Climate Studies; 1st ed. Springer, Cham, 501 p.

Backiel T., Sych R. 1958 - Resorption and spawning marks of sea trout scales in Polish waters - Rocz. Nauk Rol. 73-B: 119-158 (in Polish).

Bartel R., Auvinen H., Ikonen E. 2001 - Differences in migration pattern and growth of Polish and Finnish sea trout (Salmo trutta L.) released in the same areas - Arch. Pol. Fish. 9: 105-122.

Bartel R., Wiśniewolski W., Prus P. 2007 - Impact of the Wloclawek dam on migratory fish in the Vistula River Arch. Pol. Fish. 15: 141-156.
Bartel R., Pachur M., Bernaś R. 2010 - Distribution, migrations, and growth of tagged sea trout released into the Vistula River - Arch. Pol. Fish. 18: 225-237.

Bontemps S. 1977 - Fish migration through the fishway at a damn on the Vistula River - Gosp. Ryb. 29: 18-19 (in Polish).

Borzęcka I. 1999 - The age of migrating Vistula sea trout and the variability of smolt recruitment to the sea before damming the river - Bull. Sea Fish. Inst. Gdynia 3(148): 3-21.

Borzęcka I. 2001 - Growth of Vistula sea trout (Salmo trutta m. trutta L.) based on adults caught in the Vistula River prior to the construction of the dam in Włocławek - Bull. Sea Fish. Inst. Gdynia 2(153): 3-12.

Borzęcka I. 2003 - Characteristics of sea trout (Salmo trutta m. trutta) from the Drweca River based on scale samples collected between 1988-1992 - Arch. Pol. Fish. 11: 165-179.

Chełkowski Z. 1974 - Studies on Rega River trout (Salmo trutta L.) biology - Rozprawy AR, Szczecin, Nr 37 (in Polish).

Degerman E., Leonardsson K., Lundqvist H. 2012 - Coastal migrations, temporary use of neighboring rivers, and growth of sea trout (Salmo trutta) from nine northern Baltic Sea rivers - ICES J. Mar. Sci. 69: 971-980.

Dębowski P. 2018 - The largest Baltic population of sea trout (Salmo trutta L.): its decline, restoration attempts, and current status - Fish. Aquat. Life 26: 81-100.

Dixon B. 1931 - Age and growth rate of sea trout (Salmo trutta) in the Reda and Dunajec rivers - Prace Dz. Ekon. i Organiz. Rybactwa PAN Gosp. Wiejskiej 46 (in Polish).

ICES 2018 - Report of the Baltic Salmon and Trout Assessment Working Group (WGBAST) - 20-28 March 2018, Turku, Finland. ICES CM 2018/ACOM:10. 369 p.

Jokiel J. 1961 - Results of tagging Vistula River sea trout smolts - Gosp. Ryb. 13: 18-20 (in Polish).

Jonsson B., Jonsson N., Brodtkorb E., Ingebrigtsen P.J. 2001 - Life-history traits of brown trout vary with the size of small streams - Funct. Ecol. 15: 310-317.

Kallio-Nyberg I., Veneranta L., Saloniemi I., Jutila E., Pakarinen T. 2017 - Spatial distribution of migratory Salmo trutta in the northern Baltic Sea - Boreal Environ. Res. 22: 431-444.

Pałka W., Bieniarz K. 1983 - Migration, growth, exploitation and marking of Dunajec sea trout (Salmo trutta L.) Rocz. Nauk Rol. 100-H-2: 71-94 (in Polish).

Radtke G., Bernaś R., Płąchocki D., Prus P., Wiśniewolski W. 2018 - Does the dam in Włocławek still have an impact on the ichthyofauna of the lower Vistula River?- Some ichthyological and environmental data - Rocz. Nauk. PZW 31: 21-56 (in Polish).

Ricker W.E. 1975 - Computation and interpretation of biological statistics of fish populations - Bull. Fish. Res. Board Can. 191: 203-233. 
Shearer W.M. 1992 - Atlantic salmon scale reading guidelines - Cons. Int. Explor. Mer. ICES Cooperative Research Report, 188: 1-6.

Sych R. 1967 - Interpreting the scales of sea trout (Salmo trutta L.) from the Vistula River - Acta Hydrobiol. 9: 231-280 (in Polish).

Wąs A., Bernaś R. 2016 - Long-term and seasonal genetic differentiation in wild and enhanced stocks of sea trout (Salmo trutta m. trutta L.) from the Vistula River, in the southern Baltic - Management implications - Fish. Res.175: 57-65.

Żarnecki S. 1957 - The age and growth of seasonal populations of sea trout entering the river Vistula in autumn 1951 - ICES C.M. 1957/73.

Żarnecki S. 1963 - Occurrence of seasonal populations of Atlantic salmon (Salmo salar L.) and sea trout (Salmo trutta L.) in the Vistula River - Acta Hydrobiol. 5: 255-294 (in Polish). 